\title{
PRODUCTION OF 1,3-PROPANEDIOL BY Clostridium butyricum DSM 5431 IN AN ANAEROBIC MOVING BED BIOREACTOR
}

\author{
Teerawat Suratago, Kasidit Nootong* \\ ${ }^{1}$ Biochemical Engineering Research Unit, Department of Chemical Engineering, \\ Faculty of Engineering, Chulalongkorn University, Bangkok, 10330, Thailand. \\ kasidit.n@chula.ac.th
}

Production of 1,3-propanediol (PD) by Clostridium butyricum DSM 5431 was investigated in a moving bed bioreactor with $\mathrm{BCN}-009$ as the cell-supporting material. The results of steady state operation indicated that PD production in a moving bed bioreactor was feasible. The moving bed bioreactor provided good liquid mixing, resulting in a suitable $\mathrm{pH}$ range (i.e., $\mathrm{pH}=6.9-7.0$ ) throughout the experiment. The maximum PD concentration (33.8 g/l), product yield $(0.7)$, and productivity $(16.9 \mathrm{~g} / \mathrm{l} / \mathrm{h})$ were obtained when the bioreactor was operated using an inlet glycerol concentration and a dilution rate of $60 \mathrm{~g} / \mathrm{l}$ and 0.5 $\mathrm{h}^{-1}$, respectively. Finally, we conclude that moving bed bioreactors are attractive for future development as seen by higher effluent PD concentrations and productivity compared to other suspended-growth and immobilized bioreactor configurations.

Key words: Clostridium butyricum; glycerol; 1,3-propanediol; bioreactor; moving bed

\section{ДОБИВАЮЕ НА 1,3-ПРОПАНДИОЛ ОД Clostridium butyricum DSM 5431 ВО АНАЕРОБЕН БИОРЕАКТОР СО ПОДВИЖЕН НОСАЧ}

Испитувано е добивањето на 1,3-пропандиол (PD) од Clostridium butyricum DSM 5431 во анаеробен биореактор со подвижен носач (MB), со филтер BCN-009 како носач за клеточен материјал. Добиените резултати при динамички стационарна рамнотежна состојба покажуваат дека во биореакторот со подвижен носач е возможно добивање на PD. Со таков биореактор се овозможува добро мешање на течната фаза, при што за време на експериментот се добива погодна рН вредност (т.е. $\mathrm{pH}$ $=6,9-7,0)$. Максималната концентрација на $\mathrm{PD}(33,8 \mathrm{~g} / 1)$, приносот $(0,7)$ и брзината на производство $(16,9 \mathrm{~g} / \mathrm{l} / \mathrm{h})$ се добиваат кога и концентрацијата на глицеролот и брзината на разредувањето се $60 \mathrm{~g} / \mathrm{l}$ и $0,5 \mathrm{~h}^{-1}$. Се заклучува дека биореакторите со подвижен носач се погодни за иден развој поради повисоката концентрација на PD и брзината на производство во споредба со другите типови биореактори со носачи со суспендирани или имобилизирани култури.

Клучни зборови: Clostridium butyricum; глицерол; 1,3-пропандиол; биореактор со подвижен носач 


\section{INTRODUCTION}

1,3-propanediol (PD) is a valuable chemical used in the production of polymers, solvents, cosmetics, foods, and antifreezes [1]. Traditionally, PD is produced by the oxidation reactions of ethylene under high temperature and pressure conditions that require the use of expensive catalysts and result in the release of toxic intermediates [2]. Alternatively, PD production can be accomplished by fermenting glycerol with various bacterial strains, namely Enterobacter agglomerans, Citrobacter fruendii, Klebsiella pneumoniae, Pantoea agglomerans and Clostridium butyricum in more moderate environments compared to chemical routes $[3,4,5,6,7]$.

In terms of process development, the majority of biological PD production is confined to suspension systems rather than immobilized systems despite the latter offering various advantages, namely higher cell biomass density, elimination of washout at high dilution rates, protection against shear damage, possibility of cell reuse, and ease of separation [7, 8]. The majority of immobilized PD production systems have focused on the encapsulation of bacteria in gel-matrices or bacterial adsorption onto the surface of polymeric or natural media such as polyurethane foam, polystyrene and loofah sponges $[3,6,7,9,10]$. In our previous study, a conventional fixed bed bioreactor employed high density polyethylene (HDPE) as cell carriers to immobilize C. butyricum DSM 5431 under continuous culture conditions [10]. The maximum PD concentration and productivity reported in that work were $22.8 \mathrm{~g} / \mathrm{l}$ and $11.4 \mathrm{~g} / \mathrm{l} / \mathrm{h}$, respectively, which were comparable to results from other immobilized PD systems operating under continuous culture conditions with maximum PD concentrations and productivities in the range of 4.1 to $16.4 \mathrm{~g} / 1$ and 3.6 to $16.4 \mathrm{~g} / \mathrm{l} / \mathrm{h}$, respectively $[1,2,6,7]$. However, the setback associated with employing a fixed bed bioreactor in our previous work was the unsuitable $\mathrm{pH}$ range in the upper section of the media bed, even though the bioreactor was equipped with a $\mathrm{pH}$ control device. Inadequate mixing between the buffer solution and the bulk liquid was suggested as the main cause of poor growth conditions in the media bed [10].

In order to enhance liquid mixing and consequently obtain higher PD concentrations, a moving bed bioreactor was selected to replace the fixed bed bioreactor. In the moving bed bioreactor, microorganisms can be retained within the system due to cell attachment onto carrier surfaces while enhanced liquid mixing can be accomplished using a mechanical stirrer or by sparging gas directly into the liquid [11, 12]. Based on literature reviews, there has not yet been any report on the use of a moving bed bioreactor to accommodate glycerol conversion to PD. Therefore, a laboratory-scale moving bed bioreactor with plastic media as the cellsupporting material was built and operated to investigate the feasibility of employing a moving bed bioreactor for PD production using $C$. butyricum DSM 5431. The results obtained in this study were compared against data from our previous work using a fixed bed bioreactor.

\section{EXPERIMENTAL}

\subsection{Microorganisms}

Clostridium butyricum DSM 5431, obtained from the American Type Culture Collection (ATCC) BAA-557 ${ }^{\mathrm{TM}}$, was employed in this study. The stock culture of $C$. butyricum DSM 5431 was stored at $-20{ }^{\circ} \mathrm{C}$ in reinforced clostridial medium (RCM). RCM medium (70 ml) containing $C$. butyricum DSM 5431 was transferred into preculture medium $(630 \mathrm{ml})$ composed of glycerol $20 \mathrm{~g} / 1, \mathrm{~K}_{2} \mathrm{HPO}_{4} 1 \mathrm{~g} / \mathrm{l}$, $\mathrm{KH}_{2} \mathrm{PO}_{4} 0.5 \mathrm{~g} / \mathrm{l},\left(\mathrm{NH}_{4}\right)_{2} \mathrm{SO}_{4} 2 \mathrm{~g} / 1, \mathrm{MgSO}_{4} \cdot 7 \mathrm{H}_{2} \mathrm{O}$ $0.2 \mathrm{~g} / 1, \mathrm{CaCl}_{2} \cdot 2 \mathrm{H}_{2} \mathrm{O} 15 \mathrm{mg} / 1, \mathrm{FeSO}_{4} \cdot 7 \mathrm{H}_{2} \mathrm{O} 5$ $\mathrm{mg} / 1, \mathrm{CaCO}_{3} 2 \mathrm{~g} / \mathrm{l}$, and yeast extract $1 \mathrm{~g} / \mathrm{l}$. The preculture was grown in a 1 liter glass fermenter. Anaerobic conditions in the fermenter were achieved by constant purging of nitrogen gas at 
0.1 vvm while agitation and temperature were maintained at $125 \mathrm{rpm}$ and $33^{\circ} \mathrm{C}$, respectively. The $\mathrm{pH}$ was adjusted to 7.0 by the automatic addition of $2 \mathrm{M} \mathrm{NaOH}$. Two replicates of the 1 liter fermenter were prepared.

\subsection{Cell carrier and moving bed bioreactor}

Commercial cell carriers (i.e. BCN-009; HDPE; specific surface area $834 \mathrm{~m}^{2} / \mathrm{m}^{3}$ ) were employed to immobilize C. butyricum DSM 5431. Carriers were thoroughly washed with boiled water for 15 minutes, washed in $95 \%$ ethanol and sterilized with steam for $15 \mathrm{~min}$ utes. A total of 500 pieces of $\mathrm{BCN}-009$ media was used in this experiment. The laboratoryscale moving bed bioreactor was made from transparent acrylic with an inner diameter of 19 $\mathrm{cm}$ and a height of $25 \mathrm{~cm}$. Four baffles were constructed on the inner wall to enhance mixing. The top of the bioreactor was tightly sealed and used to accommodate a glycerol feed line, a nitrogen gas line and a $\mathrm{NaOH}$ line. Liquid mixing was achieved using a magnetic stirrer bar. Figure 1 illustrates the moving bed bioreactor system.

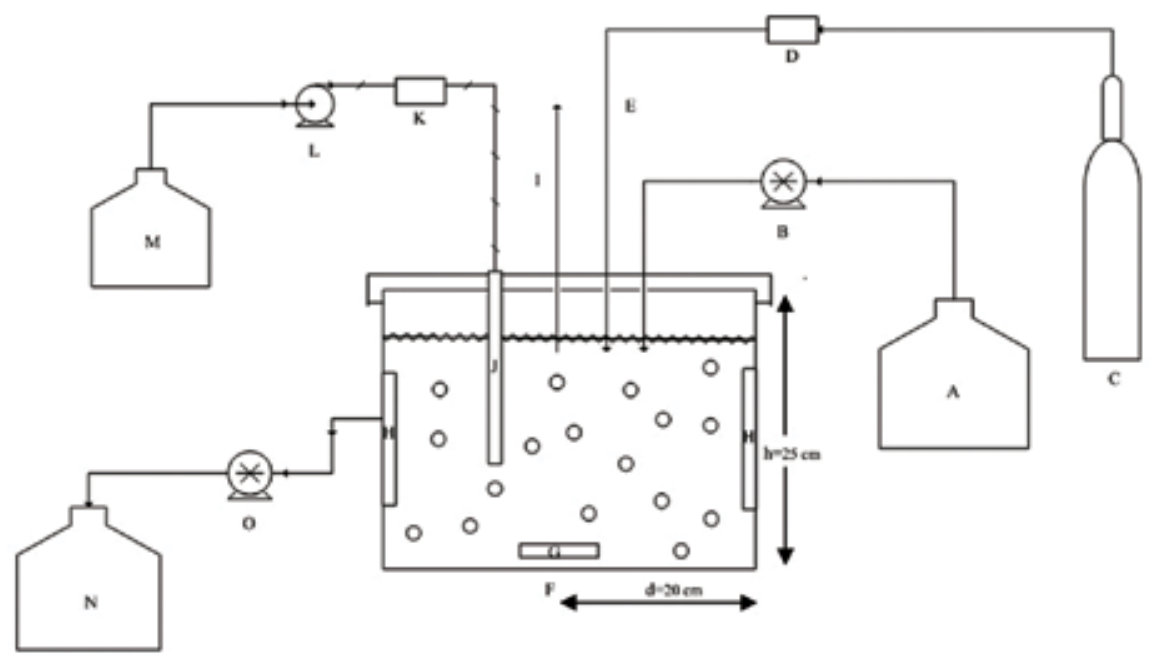

Fig. 1. Schematic drawing of a moving bed bioreactor system used in this experiment A - glycerol bottle; B - glycerol feed pump; C - nitrogen gas tank; D - nitrogen gas flow meter;

$\mathrm{E}$ - nitrogen gas line; F - bioreactor vessel; $\mathrm{G}$ - magnetic stirrer bar; $\mathrm{H}$ - baffles; I - gas purge;

$\mathrm{J}$ - pH-electrode; $\mathrm{K}$ - pH-controller; $\mathrm{L}-\mathrm{NaOH}$ pump; $\mathrm{M}-\mathrm{NaOH}$ solution bottle;

$\mathrm{N}$ - effluent collecting tank; $\mathrm{O}$ - effluent pump

\subsection{Steady state operation}

Approximately 0.81 of the $C$. butyricum DSM 5431 preculture and 3.21 of $60 \mathrm{~g} / 1$ glycerol were fed into the moving bed bioreactor to attain a working volume of 4.01 . The moving bed bioreactor was operated under batch mode for $48 \mathrm{~h}$ before the liquid was completely drained and refilled with the same amount of preculture and glycerol. Refilling and draining the preculture and glycerol were repeated three times before starting steady state operation of the moving bed bioreactor. During steady state operation, the dilution rate of the bioreactor was increased from 0.3 to $0.6 \mathrm{~h}^{-1}$ for each inlet glycerol concentration tested, namely 40, 60, 80, and $100 \mathrm{~g} / 1$. Liquid mixing by a magnetic stirrer bar was maintained at $125 \mathrm{rpm}$ while temperature and $\mathrm{pH}$ were maintained at $33^{\circ} \mathrm{C}$ and 7.0 , respectively. 


\subsection{Analytical methods}

Approximately $3 \mathrm{ml}$ of liquid sample from the bioreactor effluent line was obtained every $8 \mathrm{~h}$ during steady state operation of the moving-bed bioreactor and analyzed for the concentrations of PD and glycerol using HPLC equipped with a reactive index detector. A column (Lichrocart C18) with a length of 250 $\mathrm{mm}$ and an outer diameter of $4 \mathrm{~mm}$ was used. Operating conditions were as follows: $20 \mathrm{mM}$ $\mathrm{H}_{3} \mathrm{PO}_{4}$ as the mobile phase with a flow rate of $1.2 \mathrm{ml} / \mathrm{min}$ and column temperature at room temperature. Liquid samples were injected at a volume of $50 \mu \mathrm{l}$. Bacterial immobilization was confirmed by performing SEM (JSM-5410LV, JEOL, Japan). Both HPLC and SEM analysis were conducted at the Scientific and Technological Research Equipment Center of the Chulalongkorn University.

\section{RESULTS AND DISCUSSION}

Immobilization of $C$. butyricum DSM 5431 was initiated by feeding $60 \mathrm{~g} / 1$ of glycerol and preculture into the moving-bed bioreactor. A murky white-colored biofilm developed on the surface of cell carriers after approximately $90 \mathrm{~h}$. A slight odor of organic acids and small gas bubbles were also detectable during this time. Observation of odors and biofilm development were early signs that indicated successful establishment of microbial activities. The SEM results confirmed the successful immobilization and indicated that the morphologies of immobilized cells were mixed between rod and filament forms, and that the bacterial colonies were widely distributed over the surface of the cell carriers (Figure 2).

It is generally known that glycerol metabolism by $C$. butyricum DSM 5431 naturally produces butyric and acetic acids as byproducts and that the presence of these organic acids can reduce the $\mathrm{pH}$ of the production system into the acidic range, especially when bioreactors lack adequate $\mathrm{pH}$ control $[1,13,14]$. However, a narrow range of optimal $\mathrm{pH}$ (i.e. $\mathrm{pH}=6.6-7.0$ ) must be maintained in the bioreactor during the culture of $C$. butyricum DSM 5431 to avoid the inhibition of PD metabolic pathways [1, $15,16]$. In this study, a uniform $\mathrm{pH}$ of 6.9 to 7.0 was observed for the entire experiment and could be the consequence of maintaining wellmixed conditions in the bulk liquid as well as providing an adequate amount of buffer solu-

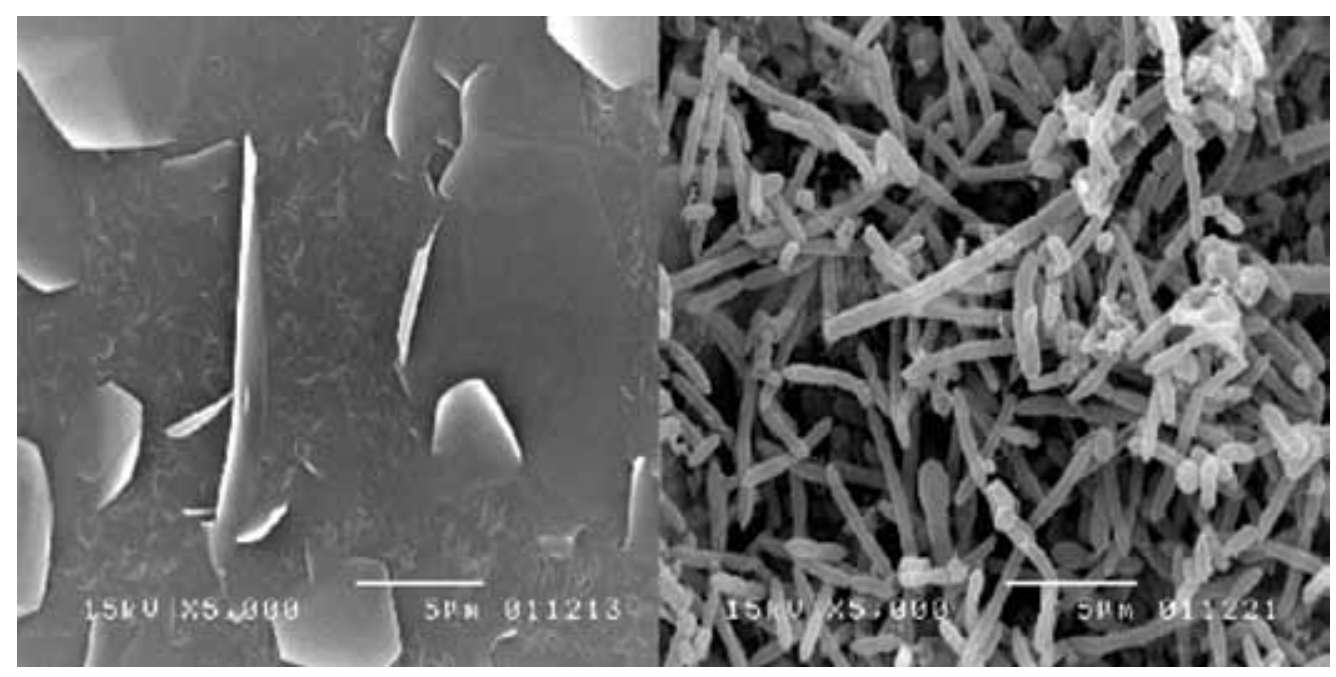

Fig. 2. Comparison between non-acclimated BCN-009 media (left) and BCN-009 immobilized with C. butyricum DSM 5431 (right) 
tion to counter organic acid production (Figure 3 ). Observation of relatively uniform $\mathrm{pH}$ in the moving bed bioreactor stood in contrast to our previous result employing a fixed bed bioreactor, where the $\mathrm{pH}$ decreased to below 6.5 in the upper section of the media bed [10].

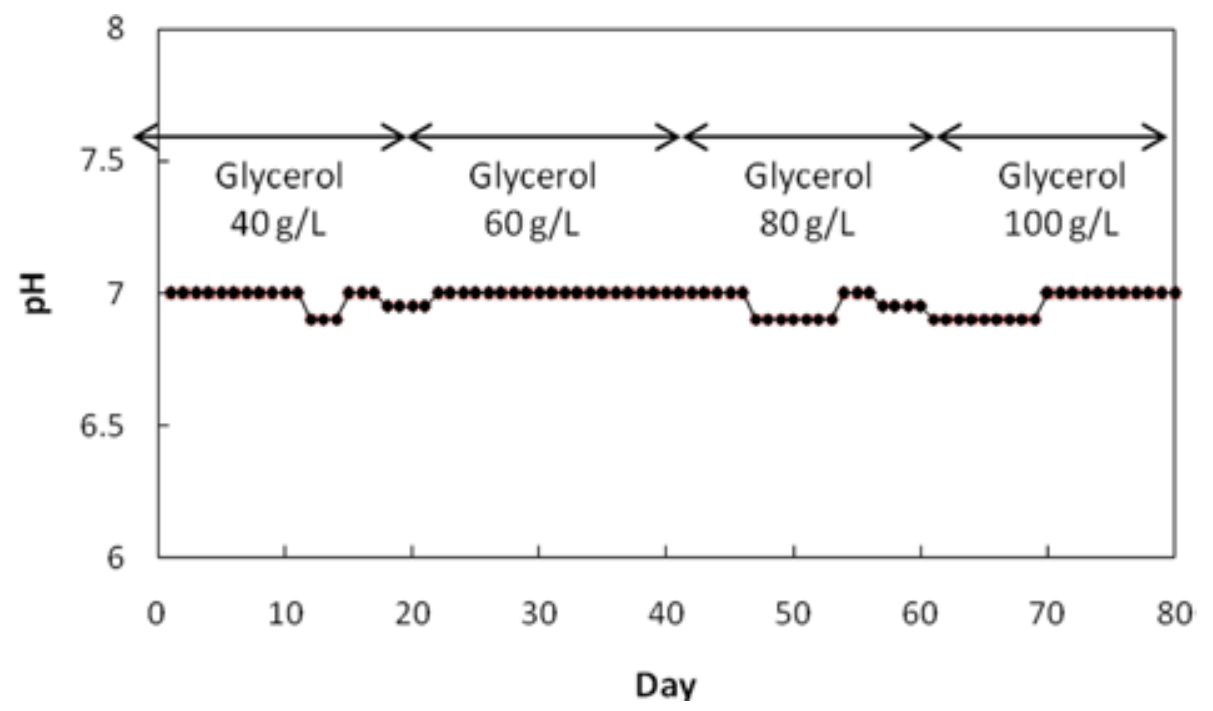

Fig. 3. The $\mathrm{pH}$ of the bulk liquid in the moving-bed bioreactor during steady state operation

The results of steady state operation demonstrated that PD production by $C$. butyricum DSM 5431 was feasible in a moving bed bioreactor with BCN-009 as the cell carrier (Figure 4). The moving bed bioreactor was continuously supplied with inlet glycerol concentrations ranging from 40 to $100 \mathrm{~g} / \mathrm{l}$ and dilution rates from 0.3 to $0.6 \mathrm{~h}^{-1}$, resulting in glycerol loading rates varying from 1.2 to $60 \mathrm{~g} / \mathrm{l} / \mathrm{h}$. The maximum PD concentration $(33.8 \mathrm{~g} / \mathrm{l})$, maximum product yield (0.7), and maximum productivity $(16.9 \mathrm{~g} / \mathrm{l} / \mathrm{h})$ were obtained when the moving bed bioreactor was operated using an inlet glycerol concentration and a dilution rate of 60 $\mathrm{g} / 1$ and $0.5 \mathrm{~h}^{-1}$, respectively. Maintaining inlet glycerol at concentrations higher than $60 \mathrm{~g} / \mathrm{l}$ appeared to decrease microbial activity, as seen by lower PD concentrations in the effluent and lower yields. This observation is in good agreement with past studies which suggest maintaining a maximum glycerol concentration of 60 $\mathrm{g} / \mathrm{l}$ and a more recent report recommending a glycerol concentration below $80 \mathrm{~g} / 1$ to avoid inhibition of microorganisms $[15,17]$. Therefore, excessive glycerol concentration was the likely explanation for lower PD concentrations and lower yields observed at the inlet glycerol concentrations of 80 and $100 \mathrm{~g} / \mathrm{l}$. Adjusting the dilution rate also affected $\mathrm{PD}$ production but to a lesser extent when compared with changing the inlet glycerol concentrations alone. In this study, effluent PD concentrations increased gradually with increasing dilution rates and declined after the dilution rate exceeded $0.5 \mathrm{~h}^{-1}$ for each inlet glycerol concentration tested

The data from steady state operation also demonstrated that a moving bed bioreactor was more suited for the continuous production of PD than a fixed bed bioreactor under comparable operating conditions. Results from our previous experiments indicated that the highest PD concentration $(22.8 \mathrm{~g} / \mathrm{l})$ and productivity $(11.4 \mathrm{~g} / \mathrm{l} / \mathrm{h})$ achieved with our fixed bed bioreactor were significantly lower than those obtained in the current study, given that the optimal operating conditions of both bioreactor systems were identical (i.e., inlet glycerol concentration $=60 \mathrm{~g} / 1$ and dilution rate $=0.5 \mathrm{~h}^{-1}$ ) [10]. In the same study, changing the type of cell carrier from plastic media to loofa sponges, which possess a higher specific surface area, was carried out in the fixed bed bioreactor as a means to increase effluent PD 

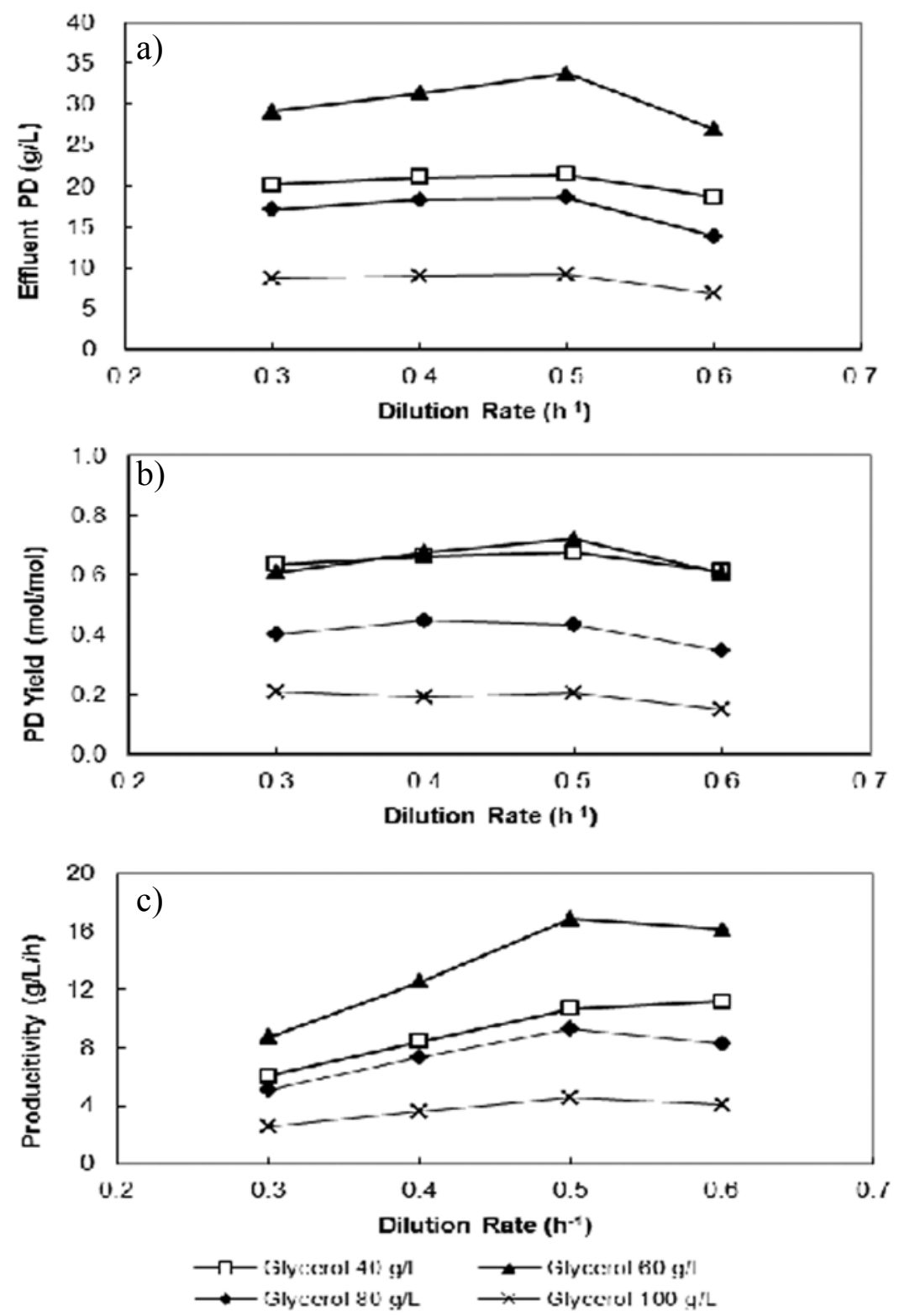

Fig. 4. Result of steady state operation of moving-bed bioreactor subjected to different inlet glycerol concentrations and dilution rates. (a) Effluent PD concentration; (b) PD yield; (c) PD productivity

concentrations. However, an overly acidic $\mathrm{pH}$ range was observed in the media bed and, despite the increase in the effluent PD concentration to $29.0 \mathrm{~g} / 1$, the maximum PD concentration remained less than that reported in this study by almost $15 \%$ [10]. The better performance of the moving bed bioreactor was perhaps related to the ability to maintain a suitable environment for microorganisms and the effective biomass retention within the system. Nevertheless, it should be pointed out that the highest PD concentration $(33.8 \mathrm{~g} / \mathrm{l})$ obtained in this study was significantly less than the yields from batch and fed-batch operations, which have reported PD concentrations in the range of 40 to $80 \mathrm{~g} / 1$ (Table 1). However, the highest productivity (i.e. $16.9 \mathrm{~g} / \mathrm{l} / \mathrm{h}$ ) from this study was by far higher than those obtained by immobilized or suspension systems and could become an attractive option for industrial-scale development. 
Ta b le 1

Biological PD production from suspended growth and immobilization systems

\begin{tabular}{|c|c|c|c|c|c|}
\hline $\begin{array}{l}\text { Fermentation } \\
\text { systems }\end{array}$ & Microorganism & $\begin{array}{l}\text { PD } \\
(g / l)\end{array}$ & $\begin{array}{c}\text { Productivity } \\
\text { (g/l/h) }\end{array}$ & Comments & Reference \\
\hline $\begin{array}{l}\text { Immobilization } \\
\text { (Moving-bed) }\end{array}$ & $\begin{array}{l}\text { C. butyricum } \\
\text { DSM } 5431\end{array}$ & 33.8 & 16.9 & $\begin{array}{l}\text { Continuous operation; Glycerol } \\
\text { feed }=60 \mathrm{~g} / \mathrm{l} \text {; Dilution rate }= \\
0.5 \mathrm{~h}^{-1} ; \mathrm{BCN}-009 \text { media. }\end{array}$ & Current work \\
\hline $\begin{array}{l}\text { Immobilization } \\
\text { (Fixed-bed) }\end{array}$ & $\begin{array}{l}\text { C. butyricum } \\
\text { DSM } 5431\end{array}$ & 22.8 & 11.4 & $\begin{array}{l}\text { Continuous operation; Glycerol } \\
\text { feed }=60 \mathrm{~g} / \mathrm{l} \text {; Dilution rate }= \\
0.5 \mathrm{~h}^{-1} ; \mathrm{BCN}-009 \text { media. }\end{array}$ & [10] \\
\hline $\begin{array}{l}\text { Immobilization } \\
\text { (Fixed-bed) }\end{array}$ & $\begin{array}{l}\text { C. butyricum } \\
\text { DSM } 5431\end{array}$ & 29 & 14.5 & $\begin{array}{l}\text { Continuous operation: Glycerol } \\
\text { feed }=60 \mathrm{~g} / \mathrm{l} \text {; Dilution rate }= \\
0.5 \mathrm{~h}^{-1} \text {; Loofa sponge as media. }\end{array}$ & [10] \\
\hline $\begin{array}{l}\text { Immobilization } \\
\text { (Fixed-bed) }\end{array}$ & C. freundii & 16.4 & 8.2 & $\begin{array}{l}\text { Continuous operation; Glycerol } \\
\text { feed }=37 \mathrm{~g} / \mathrm{l} \text {; Dilution rate }= \\
0.5 \mathrm{~h}^{-1} ; \text { Modified polyurethane } \\
\text { media. }\end{array}$ & [3] \\
\hline $\begin{array}{l}\text { Immobilization } \\
\text { (Fixed-bed) }\end{array}$ & P. agglomerans & 6.4 & 3.6 & $\begin{array}{l}\text { Continuous operation; Glycerol } \\
\text { feed }=40 \mathrm{~g} / 1 \text {; Dilution rate }= \\
0.5 \mathrm{~h}^{-1} ; \text { Polyurethane foam. }\end{array}$ & [7] \\
\hline $\begin{array}{l}\text { Immobilization } \\
\text { (Fixed-bed) }\end{array}$ & K. pneumoniae & 13.6 & 4.5 & $\begin{array}{l}\text { Continuous operation; } \\
\text { Encapsulated in } \mathrm{NaCS} / \\
\text { PDMDAAC; } \\
\text { Dilution rate }=0.33 \mathrm{~h}^{-1} \text {. }\end{array}$ & [5] \\
\hline $\begin{array}{l}\text { Suspended } \\
\text { growth }\end{array}$ & $\begin{array}{l}\text { C. butyricum } \\
\text { DSM } 5431\end{array}$ & $50-58$ & $2.0-2.3$ & $\begin{array}{l}\text { Fed-batch operation in airlift } \\
\text { reactor }\left(1.2 \mathrm{~m}^{3}\right) \text { and stirred tank } \\
\text { reactor }\left(2.0 \mathrm{~m}^{3}\right) .\end{array}$ & [14] \\
\hline $\begin{array}{l}\text { Suspended } \\
\text { growth }\end{array}$ & $\begin{array}{l}\text { K. pneumoniae } \\
\text { M5al }\end{array}$ & 58.8 & 0.92 & $\begin{array}{l}\text { Fed-batch operation in } 5,0001 \\
\text { stirred tank reactor; } \\
\text { Glycerol feed = } 15-40 \mathrm{~g} / \mathrm{l}\end{array}$ & [18] \\
\hline $\begin{array}{l}\text { Suspended } \\
\text { growth }\end{array}$ & $\begin{array}{l}\text { C. butyricum } \\
\text { DSM F2b }\end{array}$ & 46.0 & 3.4 & $\begin{array}{l}\text { Continuous two-stage operation } \\
\text { with the second stage served to } \\
\text { increase PD concentration. }\end{array}$ & [19] \\
\hline $\begin{array}{l}\text { Suspended } \\
\text { growth }\end{array}$ & $\begin{array}{l}\text { K. pneumoniae } \\
\text { oxytoca } \text { M5al }\end{array}$ & 83.6 & 1.61 & $\begin{array}{l}\text { Fed-batch operation under micro- } \\
\text { aerobic condition (air-fed); } \\
\text { Maintaining glycerol concentration } \\
\text { at } 60 \mathrm{~g} / \mathrm{l} \text { for } 6 \text { to } 40 \mathrm{~h} \text {. }\end{array}$ & [20] \\
\hline $\begin{array}{l}\text { Suspended } \\
\text { growth }\end{array}$ & $\begin{array}{l}\text { K. pneumoniae } \\
\text { DSM } 2026\end{array}$ & 72.0 & 2.1 & $\begin{array}{l}\text { Fed-batch operation under micro- } \\
\text { aerobic condition (air fed); } \\
\text { Maintaining glycerol concentration } \\
\text { between } 15 \text { and } 25 \mathrm{~g} / \mathrm{l} \text {. }\end{array}$ & [21] \\
\hline $\begin{array}{l}\text { Suspended } \\
\text { growth }\end{array}$ & $\begin{array}{l}\text { C. butyricum } \\
\text { DSM } 5431\end{array}$ & 22.8 & 16.2 & $\begin{array}{l}\text { Continuous operation; Glycerol } \\
=56 \mathrm{~g} / \mathrm{l} \text {; Cell in suspension but } \\
\text { retained by a crossflow filtration }\end{array}$ & [4] \\
\hline
\end{tabular}


In conclusion, this study assessed the production of PD from glycerol using C. butyricum DSM 5431 in a moving bed bioreactor and compared the output with our previous results utilizing a fixed bed bioreactor. PD production was found to be feasible in the moving bed bioreactor, with the maximum PD concentration, product yield, and productivity all obtained when the moving bed bioreactor was operated with an inlet glycerol concentration and a dilution rate of $60 \mathrm{~g} / \mathrm{l}$ and $0.5 \mathrm{~h}^{-1}$, respectively. Due to the ability to maintain a proper environment for microorganisms, the moving bed bioreactor was more suitable for continuous PD production by $C . b u$ tyricum DSM 5431 than the fixed bed bioreactor. We propose that moving bed bioreactors are attractive for future development, as they are relatively easy to construct and scale-up while providing effective liquid mixing. Sterilization is also possible with current technology, and, most importantly, the system provides higher productivity in comparison to suspended-growth and other immobilized bioreactor configurations.

Acknowledgment: This work was financially supported by grants from the Faculty of Engineering of the Chulalongkorn University (204-CHE-2552), from the Higher Education Research Promotion and the National Research University Project of Thailand, Office of the Higher Education Commission (FW0670B).

\section{REFERENCES}

[1] R. K. Saxena, P. Anand, S. Saran, J. Isar, Microbial production of 1,3-propanediol: Recent developments and emerging opportunities, Biotechnology Advances, 27, 895-913 (2009).

[2] A. P., Zeng, Pathway and kinetic analysis of 1,3-propanediol production from glycerol fermentation by Clostridium butyricum, Bioprocess Engineering, 14, 169-175 (1996).

[3] U. Pflugmacher, G. Gottschalk, Development of an immobilized cell reactor for the production of 1,3-propanediol by Citrobacter freundii, Applied Microbiology Biotechnology, 41, 313-316 (1994).
[4] Reimann, H. Biebl, W. D. Deckwer, Production of 1,3-propanediol by Clostridium butyricum in continuous culture with cell recycling, Applied Microbiology Biotechnology, 49, 259-363 (1998).

[5] E. H. Himmi, A. Bories, F. Barbirato, Nutrient requirements for glycerol conversion to 1,3-propanediol by Clostridium butyricum, Bioresource Technology, 67, 123-128 (1999).

[6] Y. N. Zhao, G. Chen, S. J. Yao, Microbial production of 1,3-propanediol from glycerol by encapsulated Klebsiella pneumoniae, Biochemical Engineering Journal, 32, 93-99 (2006).

[7] S. Casali, M. Gungormusler, L. Bertin, F. Fava, N. Azbar, Development of a biofilm technology for the production of 1,3-propanediol (1,3-PDO) from crude glycerol. Biochemical Engineering Journal, 64, 84-90 (2011), doi: 10.1016/j.bej.2011.11.012.

[8] M. L. Shuler, F. Kargi, Bioprocess Engineering Basic Concepts, Prentice-Hall, Englewood-Cliffs, New Jersey, 1992.

[9] M. S. Griffiths, J. A. Bosley, Assessment of macroporous polystyrene-based polymers for the immobilization of Citrobacter freundii, Enzyme and Microbial Technology, 15, 109-113 (1993).

[10] T. Suratago, Immobilization of Clostridium butyricum DSM 5431 on loofa sponges in fixed bed bioreactors for the production of 1,3-propanediol, Master thesis in chemical engineering, Chulalongkorn University, 2009.

[11] H. Li, H. Han, M. Du, W. Wang, Removal of phenols, thiocyanate and ammonium from coal gasification wastewater using moving bed biofilm reactor, Bioresource Technology, 102, 4667-4673 (2011).

[12] S. Wang, N. Chandrasekhara Rao, R. Qui, R. Moletta, Performance and kinetic evaluation of anaerobic moving bed bioreactor for treating milk permeate from dairy industry, Bioresource Technology, 100, 5641 - 5647 (2009).

[13] F. Barbirato, E. H. Himmi, T. Conte, A. Bories, 1,3-Propanediol production by fermentation: An interesting way to valorize glycerin from the ester and ethanol industries, Industrial Crops and Products, 7, 281-289 (1998).

[14] J. Mongkolkajit, J. Pullsirisombat, S. Prichanont, V. Tantayakom, P. Prasitchoke, M. Phisalaphong, $\gamma$-Alumina doped alginated gel for cell immobilization in fermentation processes, Proceeding to Regional Symposium in Chemical Engineering, Kuala Lumpur, Malaysia, 2008, pp. 51-60. 
[15] J. Pullsirisombat, $\gamma$-Alumina doped alginate gel for cell immobilization in fermentation processes, Master thesis in chemical engineering, Chulalongkorn University, 2007.

[16] B. Gunzel, S. Yonsel, W. D. Deckwer, Fermentative production of 1,3-propanediol from glycerol by Clostridium butyricum up to a scale of $2 \mathrm{~m}^{3}$, Applied Microbiology Biotechnology, 36, 3628926294 (1991).

[17] H. Biebl, Glycerol fermentation of 1,3-propanediol by Clostridium butyricum. Measurement of product inhibition by use of a $\mathrm{pH}$-auxostat, Applied Microbiology and Biotechnology, 35, 701-705 (1991).

[18] K. K. Cheng, J. A. Zhang, D. H. Liu, Y. Sun, H. J. Liu, M. D. Yang, J. M. Xu, Pilot-scale production of 1,3-propanediol using Klebsiella pneumonia, Process Biochemistry, 42, 740-744 (2007).
[19] S. Papanikolaou, P. Ruiz-Sanchez, B. Pariset, F. Blanchard, M. Fick, High production of 1,3-propanediol from industrial glycerol by a newly isolated Clostridium butyricum strain, Journal of Biotechnology, 77, 191-208 (2000).

[20] G. Yang, J. Tian, J. Li, Fermentation of 1,3-propanediol by lactate deficient mutant of Klebsiella oxytoca under microaerobic conditions. Applied Microbiology Biotechnology, 73, 1017-1024 (2007).

[21] H. J. Liu, D. J. Zhang, Y. H. Xu, Y. Mu, Y. Q. Sun, Z. L. Xiu, Microbial production of 1,3-propanediol from glycerol by Klebsiella pneumonia under micro-aerobic condition up to a pilot scale. Biotechnology Letter, 29, 1281-1285 (2007).

[22] A. Reimann, H. Biebl, Production of 1,3-propanediol by Clostridium butyricum DSM 5431 and product tolerant mutants in fed-batch culture: feeding strategy for glycerol and ammonium. Biotechnology Letter, 18, 827-832 (1996). 
